\title{
Analysing OECD National Contact Point Statements for Guidance on Human Rights Due Diligence Method, Findings and Outlook
}

Buhmann, Karin

Document Version

Accepted author manuscript

Published in:

Nordic Journal of Human Rights

DOI:

$10.1080 / 18918131.2018 .1547526$

Publication date:

2018

License

Unspecified

Citation for published version (APA):

Buhmann, K. (2018). Analysing OECD National Contact Point Statements for Guidance on Human Rights Due Diligence: Method, Findings and Outlook. Nordic Journal of Human Rights, 36(4), 390-410.

https://doi.org/10.1080/18918131.2018.1547526

Link to publication in CBS Research Portal

\section{General rights}

Copyright and moral rights for the publications made accessible in the public portal are retained by the authors and/or other copyright owners and it is a condition of accessing publications that users recognise and abide by the legal requirements associated with these rights.

\section{Take down policy}

If you believe that this document breaches copyright please contact us (research.lib@cbs.dk) providing details, and we will remove access to the work immediately and investigate your claim. 


\title{
Analysing OECD National Contact Point Statements for Guidance on Human Rights Due Diligence: Method, Findings and Outlook
}

\author{
Karin Buhmann
}

Journal article (Accepted manuscript*)

Please cite this article as:

Buhmann, K. (2018). Analysing OECD National Contact Point Statements for Guidance on Human Rights Due Diligence: Method, Findings and Outlook. Nordic Journal of Human Rights, 364), 390-410. https://doi.org/10.1080/18918131.2018.1547526

This is an Accepted Manuscript of an article published by Taylor \& Francis in Nordic Journal of Human Rights on 21 Dec 2018, available online:

DOl: http://www.tandfonline.com/10.1080/18918131.2018.1547526

* This version of the article has been accepted for publication and undergone full peer review but has not been through the copyediting, typesetting, pagination and proofreading process, which may lead to differences between this version and the publisher's final version AKA Version of Record. 


\title{
Analysing OECD National Contact Point statements for guidance on human rights due diligence: method, findings and outlook*
}

\begin{abstract}
:
This article examines statements issued by National Contact Points (NCPs) under OECD's Guidelines for Multinational Enterprises. Applying the term 'risk-based due diligence', OECD's Guidelines have adopted the human rights due diligence concept introduced by the UN Framework and elaborated by the UN Guiding Principles. OECD NCPs de facto serve as remedy institutions for those instruments. The analysis aims to identify and glean insights provided by NCPs on human rights due diligence. It identifies and analyses specific instances that have addressed due diligence in regard to state guidance for companies operating in conflict areas and the identification of a business relationship as 'directly linked' in the terms of the UNGPs and the Guidelines. It also considers steps that form part of due diligence, particularly stakeholder engagement, the exercise of influence through leverage, and integrating and acting upon findings on impact. The article finds that final statements and recommendations issued by NCPs can serve as sources of norms for human rights/risk-based due diligence. It also finds that there appears to be scope for a larger number of NCPs to deliver guidance through their final statements.
\end{abstract}

Key words: directly linked business relationships; human rights due diligence; human rights impact assessment; leverage; meaningful stakeholder consultation; National Contact Points (OECD).

\section{Introduction}

Responding to concerns regarding the capacity of businesses to adversely impact human rights, the United Nations (UN) Secretary General in 2005 appointed a special representative on business and human rights. This special procedure appointment resulted in two reports: the 'Protect, Respect and Remedy Framework' ('UN Framework'), ${ }^{1}$ adopted by the UN Human Rights Council in 2008 and the UN Guiding Principles ('UNGP'), adopted in 2011. ${ }^{2}$ Developed through multi-stakeholder processes, ${ }^{3}$ the two reports set out guidance for states and companies with a view to preventing and managing adverse business impacts on human rights, and to provide remedy when business-related human rights abuse is perceived to have occurred. Both reports are structured around three 'pillars': the State Duty to Protect, the Corporate Responsibility to Respect, and Access to Remedy. The first pillar elaborates states' existing human rights obligations from the perspective of the duty to protect against human rights harm caused by third parties, including through the provision of adequate guidance for home-state based companies. The second pillar explains steps companies should take to ensure they respect human rights. Companies' adoption of a process of 'human rights due diligence' is set out by the UN Framework as a key element. Directed at identifying, preventing, mitigating and accounting for actual or potential harm caused by a company to society, the due diligence process involves a series of steps that are elaborated in some level of detail by the UNGP. The third pillar is based on recognition of the importance of access to remedy as a human right in its own right, also acknowledging that the need for remedy may arise even when companies exercise due diligence. The reports note that remedy for business-related human rights abuse may be provided by various institutions, which they group into state-based judicial and nonjudicial as well as non-state operational level procedures.

\footnotetext{
* This article has benefited from the comments of two anonymous reviewers, and research time provided through the SMART research project, funded under the European Union's Horizon 2020 Research and Innovation Programme under Grant Agreement No. 693642, project SMART (Sustainable Market Actors for Responsible Trade). The contents of this article are the sole responsibility of the author and do not necessarily reflect the views of the European Union.

1 'Protect, Respect and Remedy: a Framework for Business and Human Rights' (7 April 2008) UN Doc A/HRC/8/5 [hereinafter 'Framework'].

2 'Guiding Principles on Business and Human Rights: Implementing the United Nations "Protect, Respect and Remedy" Framework' (21 March 2011) UN Doc A/HRC/17/31 [hereinafter 'UNGP'. Specific Guiding Principles are referenced 'GP'].

${ }^{3}$ J. Ruggie, Just Business (Norton 2013).
} 
Among state-based, non-judicial remedy institutions, the UN Framework highlighted National Contact Points (NCPs) to the OECD. ${ }^{4}$ Under a binding OECD Decision, ${ }^{5}$ a state that adheres to OECD's Guidelines for Multinational Enterprises (the Guidelines) ${ }^{6}$ commits to establishing an NCP. Charged with promoting and implementing the Guidelines, NCPs have a dual role: providing information of the Guidelines and their substantive points, and handling of 'specific instances' (complaints) concerning alleged non-observance of the Guidelines. ${ }^{7}$ NCPs therefore play both a preventative pro-active role and a reactive remedial one. As the Guidelines in line with the UN Framework and UNGP have a predominant 'do no harm' focus, even remedial action should ideally lead to reduced harm in the future.

A 2011 revision of the Guidelines incorporated a human rights chapter designed to be in line with the UNGP. The revision also adopted the human rights due diligence approach and extended it to most of the issue areas covered by the Guidelines, introducing the term 'risk-based due diligence. NCPs therefore are de facto remedial institutions for the UN Framework and UNGP. As explained by Ceyhan, ${ }^{8}$ this means that NCP's 'jurisprudence' or statements following their handling of a complaint can serve as sources of norms on business conduct in accordance with the UNGP. This article engages with that issue, on the assumption that NCP jurisprudence can be of value in, at least, the following contexts: First, they can help the company challenged by a complaint understand how it can better live up to expectations under the Guidelines and therefore implicitly the UN Framework and UNGP in the future. Second, being based on assessments of corporate conduct in specific contexts, NCP statements can help other companies understand what is required by due diligence. Third, NCP statements they can feed into other NCP work to promote knowledge on risk-based due diligence by providing examples and guidance and thereby potentially contributing to the development of a coherent jurisprudence across NCPs. The latter is noted with some reservation since the state-based character of NCPs means they operate individually under various organisational and operational structures. Yet it is also a potentially important element in streamlining the promotion of the Guidelines to companies operating in or from the many countries adhering to the Guidelines. Finally, NCP statements can offer insights to scholars and organisations interested in responsible business conduct, whether to advise companies or to hold them to account.

Risk-based due diligence is still a novel concept, management approach and standard by which companies are held to account in front of remedy institutions as well as through their 'social license to operate'. ${ }^{9}$ The OECD and the Office of the High Commissioner for Human Rights (OHCHR) have developed general and some sector-specific guidance documents. ${ }^{10}$ As NCP statements build on assessments of specific cases of actual company conduct and impacts, they can be expected to offer additional sources of guidance. NCP statements are under-researched with only little academic work being done on them so far, ${ }^{11}$ despite an emergent scholarly debate on what risk-based due diligence entails. ${ }^{12}$ NCPs do not have powers to issue enforceable judgments, but they do fill a remedy gap for

\footnotetext{
${ }^{4}$ Framework, para. 98.

${ }^{5}$ Decision of the Council on the Guidelines for Multinational Enterprises, OECD Decision C(2000)96/FINAL as amended by OECD Decision C/MIN(2011)11/FINAL

${ }^{6}$ OECD Guidelines for Multinational Enterprises, 2011 edition (25 May 2011) [hereinafter 'Guidelines].

${ }^{7}$ GP, II: Implementation Procedures, I.1.

${ }^{8}$ Compare also Basak Baglayan Ceyhan in this issue; Basak Baglayan Ceyhan, Corporations and Human Rights: Searching for international norms for corporate conduct in domestic case law (PhD dissertation, Luxembourg University 2017).

${ }^{9}$ Compare D.B. Spence (2011) 'Corporate social responsibility in the oil and gas industry: The importance of reputational risk’, 86 (2011) 1 Chicago-Kent Law Review 59-85; Ruggie (n 3) 10, 17-18, 135-139.

${ }^{10}$ The Corporate Responsibility to Respect Human Rights: An Interpretive Guide, Office of the High Commissioner for Human Rights: New York and Geneva. OECD's general and sector guidances (incl. responsible supply chains for several sectors) are available through http://www.oecd.org/investment/due-diligence-guidance-for-responsible-business-conduct.htm. ${ }^{11}$ See in particular, L.C. Backer, 'Rights and Accountability in Development (Raid) vs. Das Air and Global Witness v. Afrimex - Small Steps towards an Autonomous Transnational Legal System for the Regulation of Multinational Corporations', 10 (2009)1 Melbourne Journal of International Law 258-307; J. Ruggie and T. Nelson, 'Human Rights and the OECD Guidelines for Multinational Enterprises: Normative innovations and implementation challenges', Harvard Kennedy School/Corporate Social Responsibility Initiative Working Paper No. 66, May 2015, and Ceyhan (2017, n 8). ${ }^{12}$ E.g., Robert McCorquodale, Lise Smith, Stuart Neely and Robin Brooks, 'Human Rights due diligence in law and practice: Good practices and challenges for business enterprises', 3(2017)2 Business and Human Rights Journal,
} 
transnational business operations and their social impacts. Being empowered to handle complaints of abuse in countries that do not have their own NCPs, provided there is a connection to the country of the handling NCP, NCPs have extraterritorial reach that courts rarely enjoy. However, the fact that NCPs vary in regard to independence, organisation, resources as well as approaches to making determinations or recommendations in their final statements also potentially limits that role. ${ }^{13}$ Adopted in 1976, the Guidelines have been revised at intervals. The 2011 revision not only adopted the risk-based due diligence approach ${ }^{14}$ but also sub-concepts introduced by the UN Framework and elaborated with the UNGP. These include 'meaningful consultations'/'effective stakeholder engagement', the exercise of influence or 'leverage', and the distinction between whether a business itself causes or contributes to harm, or is connected to harm through business relations that are directly linked through operations, products or services. Risk-based due diligence is itself a complex practice which covers a set of interrelated actions. Intended to be a standard of conduct rather than a standard of result, ${ }^{15}$ it spans from the inception of an activity to remedying its adverse impacts. The 2011 expansion of the application of due diligence beyond human rights to, i.a., corporate impact on the environment, labour/industrial relations and anti-corruption further increased the pertinence of guidance for risk-based due diligence.

Studying NCP statements therefore offers a potential method to gain insights into human rights due diligence through the ongoing elaboration, explanation and construction of what that concept entails. This article engages with that task by explaining how such an analysis can be designed in order to identify relevant NCP statements drawing on available databases, and by performing an exemplary identification and analysis. This serves to test the assumption that such statements are an important source of normative guidance, and to identify whether organisational differences between NCPs has an effect on the role of NCP statements as sources of normative guidance.

The subsequent section provides contextual information on the Guidelines, NCPs, and due diligence. This is followed by an explanation of the potential significance of NCP statements as guidance for responsible business conduct, exemplified by some previous NCP statements that have been debated in the literature as leading, or which have explicitly shaped the OECD's work. Next, it explains how NCP statements can be selected for an analysis of guidance on particular issues. The subsequent exemplary analysis of NCP statements identifies guidance on due diligence and its sub-elements, followed by a discussion and reflection. The conclusion sums up and offers some perspectives for NCP statements to fulfil their potential to deliver guidance.

\section{Context}

\subsection{OECD's Guidelines and National Contact Points}

OECD's Guidelines for Multinational Enterprises is a normative framework for what the OECD refers to as 'responsible business conduct'. The Guidelines cover several issue areas, including disclosure, human rights, employment/industrial relations (labour standards), environment and anti-corruption.

Governments adhering to the Guidelines commit to encouraging companies set up or operating on their territories to observe the Guidelines. ${ }^{16}$ This provides the Guidelines with global applicability, if the company in question is registered in an adhering state or operates in one. Adherence to the Guidelines is

\footnotetext{
doi:10.1017/bhj.2017.2; J. Bonnitcha \& R. McCorquodale, "The concept of "due diligence” in the UN Guiding Principles on Business and Human Rights', 28(2017)3 European Journal of International Law, online at http://www.ejil.org/article.php?article=2794\&issue=137 (accessed 11 October 2018); B. Fasterling and G. Demuijnck, Human Rights in the Void? Due Diligence in the UN Guiding Principles on Business and Human Rights', 116(2013)4 Journal of Business Ethics 799-814; O. Martin-Ortega, 'Human Rights Due Diligence for Corporations: From voluntary standards to hard law at last?', 32(2014)1 Netherlands Quarterly of Human Rights, 44-67; B. Fasterling, 'Human Rights Due Diligence as Risk Management: social risk versus human rights risk', 2(2016)2 Business and Human Rights Journal $225-247$.

13 OECD, Structures and Procedures of National Contact Points for the OECD Guidelines for Multinational Enterprises (2018 OECD).

${ }^{14}$ Guidelines, Chapter II, Commentary 14; compare GP 15(b).

15 J. Ruggie and John F. Sherman III, "The Concept of "Due Diligence" in the UN Guiding Principles on Business and Human Rights: A Reply to Jonathan Bonnitcha and Robert McCorquodale', 28(2017)3 European Journal of International Law, available at http://www.ejil.org/article.php?article=2799\&issue $=137$.

${ }^{16}$ Guidelines, Chapter 1, para. 3.
} 
not limited to OECD Member States. Currently, 12 non-OECD states are declared adherents. ${ }^{17}$ This increases global applicability, and therefore also the potential role of NCPs as remedy institutions providing elaboration of responsible company conduct in various contexts.

Whereas the first part of the Guidelines contains normative directives for companies, the second part provides implementation procedures for NCPs and their complaints handling. The Guidelines indicate that in handling complaints, NCPs should offer their 'good offices' to help the parties involved resolve the issue. This includes providing access to non-adversarial conflict resolution (typically mediation). ${ }^{18}$ As such, the procedure is informed by an aim of contributing to 'win-win' solutions in line with alternative dispute resolution theory. ${ }^{19}$ Depending on the outcome of mediation and the NCP's own investigations, NCP statements may include findings of whether the company acted in accordance with the Guidelines, and recommendations on the company's future actions. ${ }^{20}$ Published NCP statements that criticise company conduct explicitly or do so implicitly through recommendations for changed conduct may cause reputational damage for the company. This can affect their 'social licence to operate" ${ }^{21}$ and their economic situation, thus directly impacting the core foundations for an economic enterprise. The desire to avoid such criticism can therefore act as a driver for companies to act in accordance with the Guidelines. Detailed guidance can help companies in that regard.

The issuance and character of an NCP statement depends on the stage of the complaints handling process. According to the procedural provisions of the Guidelines, the NCP first conducts an initial assessment to evaluate whether the issue raised merits further examination. It either accepts the case, or publishes a statement explaining why the case was not accepted. If the case is accepted, the NCP assists the parties in reaching an understanding and possibly entering into an agreement. An agreement may include a restitution of the harm incurred, and steps to be taken by the company to avoid similar issues from arising in the future. Finally, at the end of the process the NCP publishes a final statement regarding the issues raised in the case, the support offered by the NCP, and the outcomes. Final statements may contain recommendations to the parties. Some NCPs take this opportunity to make quite detailed recommendations. The Guidelines require an NCP's final statement on the outcome to be made public, whether or not the parties reach an agreement. NCPs therefore do not have much leeway in terms of the procedure or the issuance of statements, but they do have discretion as to including recommendations in final statements. Their practices differ considerably in this regard, and, as result, the extent of forward-looking guidance provided also differs.

Being non-judicial remedy institutions, NCPs cannot impose sanctions, directly provide compensation or even compel parties to participate in a conciliation or mediation process. However, this does not deprive them of importance in shaping business conduct through findings on what action a company should have undertaken to act in accordance with the Guidelines, or recommendations for future conduct. ${ }^{22}$

Since 2000, NCPs have received more than 400 complaints relating to company operations in over 100 countries and territories, relating to the Guidelines' various issue areas. Following the 2011 revision there has been a significant increase in complaints relating to human rights as well as the Guidelines' chapter on 'General Principles' which include risk-based due diligence. ${ }^{23}$ Between 2011 and 2016, 47 per cent of all cases accepted for examination by NCPs resulted an agreement between the parties based

\footnotetext{
${ }^{17}$ OECD website: Guidelines for Multinational Corporations - National Contact Points, http://mneguidelines.oecd.org/ncps/ (accessed 11 October 2018).

${ }^{18}$ Guidelines, Procedural Guidance, C.2.d.

${ }^{19}$ Vibeke Vindeløv, Konflikt, tvist og magling: konfliktlфsning ved forhandling (Akademisk Forlag 1997).

${ }^{20}$ Guidelines, Procedural Guidance, C.3.

${ }^{21}$ G. Demuijnck \& Björn Fasterling, 'The Corporate Social License to Operate', 136(2016)4 Journal of Business Ethics, 675685.

${ }^{22}$ Compare Ceyhan (this issue).

${ }^{23}$ C. Daniel, J. Wilde-Ramsing, K. Genovese and V. Sandjojo Remedy remains rare: an analysis of 15 years of NCP cases and their contributions to improve access to remedy for victims of corporate misconduct (2015 OECD Watch).
} 
on mediation or other aspects of the good offices of the NCPs, and 37 per cent in an internal policy change by the company. ${ }^{24}$

Despite being established by an international law instrument, NCPs are state-based. This means that they do not have uniform organisational structures. To limit divergence, the Guidelines establish that NCPs should act under the principle of "functional equivalence" ${ }^{25}$ and have set out core criteria for that purpose. Coordination and sharing of experience are supported by various activities organised by the Paris-based secretariat and by NCP reports to the OECD Investment Committee (the body responsible for the Guidelines). ${ }^{26}$ Such coordination approximates the practice of international and regional courts and treaty procedures on human rights to develop a coherent jurisprudence, even across institutional systems (such as across the ILO and Council of Europe). A similar extent of coordination has not fully been the case for NCPs so far, ${ }^{27}$ but arguably would be a step in the direction of enhancing functional equivalence. Studies show that, in practice, considerable differences exist between NCPs organisation and operations, and their deployment of statements and recommendations related to complaints. ${ }^{28}$

\subsection{Risk-based due diligence}

An essential element in the corporate responsibility to respect human rights as defined by the UNGPs, human rights due diligence is a management process to identify, prevent and mitigate adverse impact on human rights, to account for how impact is addressed, and to provide remedy for harmful impacts that have occurred. ${ }^{29}$ Due to formal page constraints, the UNGP report was not able to elaborate the steps of the due diligence process in great detail. In providing operational guidance for the concept as introduced by the UN Framework, the UNGPs elaborate core sub-elements of the due diligence process. ${ }^{30}$ These include meaningful stakeholder consultation; ${ }^{31}$ and the responsibility of the enterprise to integrate and act upon findings from its impact assessments across relevant internal functions and processes. ${ }^{32}$ It also includes the distinction between whether a company causes or contributes to an adverse impact, or whether it is involved because the impact is directly linked to the operations, products or services by a business relationship, calling for the exercise of leverage. ${ }^{33}$ Moreover, the UNGPs explain that states' provision of guidance for enterprises on due diligence constitutes part of their duty to protect. $^{34}$

Human rights due diligence and, by implication, risk-based due diligence, according to OECD's Guidelines, differ in some key ways from the due diligence approach that is well-known from legal practice related to identifying economic risks or liability, such as in connection with mergers and acquisitions. First of all, the direction of risk-based due diligence is from the company to society, aiming to protect society against harm caused by the company as opposed to protecting the company from risk caused by society. ${ }^{35}$ Moreover, risk-based due diligence is an ongoing process that only ends when an activity is fully over.

${ }^{24}$ OECD, Cases handled by the National Contact Points for the OECD Guidelines for Multinational Enterprises, (2015 OECD), https://mneguidelines.oecd.org/Flyer-OECD-National-Contact-Points.pdf (accessed 7 October 2018).

${ }^{25}$ Guidelines: Procedural Guidance, I.A.

${ }^{26}$ For a detailed discussion of NCP collaboration and relations to the Investment Committee, see Ceyhan (2017, n 8).

${ }^{27}$ This was evidenced by a variation in NCP final statements in three cases concerning the POSCO company, lodged with the NCPs of Korea, Norway and the Netherlands. See discussion in Ceyhan (2017, n 8) 228-229.

28 OECD (n 13).

${ }^{29}$ GP 17 with commentary.

${ }^{30}$ GPs 17-21.

${ }^{31}$ GP 18.

${ }^{32}$ Guidelines, Chapter IV, para. 45, compare GP 19.

${ }^{33}$ Guidelines, Chapter II,A, paras 11-12 and Commentary 14, Chapter VI, paras. 2-3; compare GP 17 and 19 with commentaries; OECD Guidelines, Chapter IV, Commentary 43.

${ }^{34}$ This applies in particular to firms owned or controlled by the state as well as firms operating in conflict zones (GP 4 and 7 with commentaries) but may in principle be relevant to other firms as well.

${ }^{35}$ As noted by the OHCHR (above, n. 10), human rights due diligence "should not be confused with other forms of legal due diligence activities, such as those carried out in preparation for corporate mergers and acquisitions, or those required for compliance monitoring purposes in areas such as banking or anticorruption. The key difference between these concepts is that the latter group is generally concerned with identifying, preventing, and mitigating risks to business; whereas human rights due diligence is concerned with risks to people." See also Ruggie and Sherman (n. 15) and Working Group on Business and 
While the academic debate has both welcomed ${ }^{36}$ and criticised the UNGP's due diligence approach, ${ }^{37}$ it has also been observed that NCPs can contribute to substantively defining what risk-based due diligence entails. $^{38}$

\section{The potential of NCP statements as guidance for due diligence}

The UN Framework described due diligence as a process whereby companies not only ensure compliance with national laws but also manage the risk of human rights harm with a view to avoiding $i t .{ }^{39}$ In many areas concerning adverse business impacts on society, the need for remedy is ideally avoided because the adverse impact is irreparable. Studies indicate that even where remedy is available, its effectiveness to restore human rights harm is questionable. ${ }^{40}$ Hence, however important remedy is, prevention of harm is preferable. The elaboration of what specific types of action or considerations a business enterprise should engage in, in order to act with due diligence and therefore identify and manage harmful impacts before they occur, is significant because the more knowledge businesses have of what risk-based due diligence entails, the better their chances of acting appropriately.

Leaning on the UNGPs, the OECD Guidelines recognise that human rights due diligence is contextspecific $^{41}$ and may require prioritisations to address the most salient harmful impacts first. For example, for extensive or complex value chains where it may be difficult for the company to assess and monitor human rights risks throughout, it may need to prioritise its actions according to where risks for severe impact are higher. ${ }^{42}$ Such prioritisation, too, can benefit from insights from situations encountered by other companies, again underscoring the potential role of NCP jurisprudence that can serve pro-actively as guidance for other companies.

The UNGPs emphasise meaningful stakeholder consultation as an element in the exercise of due diligence to identify and manage adverse impact. ${ }^{43}$ The Guidelines refer to effective stakeholder engagement and provide examples of the process (e.g., 'meetings, hearings or consultation proceedings') and contexts (e.g., 'the planning and decision-making concerning projects or other activities involving, for example, the intensive use of land or water, which could significantly affect local communities'). ${ }^{44}$ However, what meaningful stakeholder consultation or stakeholder engagement actually entails in particular situations is neither prescribed by the UNGPs, nor the OECD Guidelines. Guidance from cases handled by NCPs can contribute relevant direction for companies.

The same arguments can be made for other sub-concepts of due diligence, such as when a company is being directly linked to adverse impacts through business relationships, and what 'leverage' entails in such contexts. The UNGP and Guidelines use 'leverage' to indicate the use of influence to seek to change conduct with another organisation, whether public or private, involved in adverse impact. ${ }^{45}$ Leverage is therefore a key instrument for a company that does not itself cause adverse harm in order to

Human Rights, Companion note I to the Working Group's 2018 report to the General Assembly (A/73/163) Corporate human rights due diligence - Background note elaborating on key aspects, 16.10.2018, https://www.ohchr.org/Documents/Issues/Business/Session18/CompanionNote1DiligenceReport.pdf (accessed 27 October 2018).

${ }^{36}$ E.g., Martin-Ortega (n 12);K. Buhmann, 'Neglecting the proactive aspect of human rights due diligence? A critical appraisal of the EU's Non-Financial Reporting Directive as a Pillar One avenue for promoting Pillar Two action', 3(2017)1 Business and Human Rights Journal, 23-45. M. Footer, 'Human Rights Due Diligence and the Responsible Supply of Minerals from Conflict-affected Areas: Towards a Normative Framework?', in J.L. Černič and T.V. Ho (eds), Direct Human Rights Obligations of Corporations (2015 Wolf) 179.

${ }^{37}$ E.g., Fasterling and Demuijnck (n 12); Fasterling (n 12), supra note 21; Bonnitcha \& McCorquodale (n 12); but compare Ruggie and Sherman (n 15).

${ }^{38}$ Ceyhan $(2017$, n 8) 249.

${ }^{39}$ Framework, para. 25, emphasis added.

${ }^{40}$ Daniel et al. (n 23).

${ }^{41}$ Guidelines, Chapter II, Commentary 15, compare GP 17(b).

${ }^{42}$ Guidelines, Chapter II, Commentary 16.

${ }^{43}$ GP 3, Commentary, and GP 21 with commentary.

${ }^{44}$ Guidelines, Chapter II, Commentary 25, compare GP 3, Commentary, and GP 21 with commentary.

${ }^{45}$ GP 19; Guidelines Chapter II, Commentary on General Principles, para. 19. 
influence businesses with which it has relations and which are involved in such harm to change their conduct With rising awareness of, for example, the potential connection of institutional investors to impacts caused by invested companies, it becomes increasingly pertinent for such investors and their stakeholders (e.g., individuals whose pensions are invested by institutional investors) to understand how investors should exercise leverage. NCP statements can help explain this, and help clarify other types of business relationships calling for the exercise of leverage.

In their procedural directives for NCPs, the Guidelines note that in handling complaints, NCPs are required to take into account how similar issues have been, or are being, treated in other domestic or international proceedings. ${ }^{46}$ The UK NCP has noted that the OECD 'has not suggested to NCPs that their findings in complaints should establish precedents', unless, it added, 'they have been the subject of referrals to the relevant OECD Committees'. ${ }^{47}$ Thus, while NCP statements are not by themselves precedents or intended to be so according the Guidelines, they may attain a precedent status through decisions by the OECD. ${ }^{48}$ Even in the absence of such formal elevation to precedence, NCP statements may still offer guidance for companies as well as for other NCPs in regard to similar or related substantive issues.

Some NCP statements have already been analysed and referenced by the literature ${ }^{49}$ in a manner that underscores the potential for the elaboration of risk-based due diligence. In RAID vs. Das Air, ${ }^{50}$ the NGO Rights and Accountability in Development (RAID) complained that DAS Air was involved in the transportation of coltan (a rare earth mineral) from the conflict-ridden eastern Democratic Republic of Congo (DRC) to the benefit of a rebel group operating in that area. DAS Air was a cargo airline operating out of several hubs. The company argued that it was contracted by freight forwarders. It denied having been aware that the transported coltan originated from DRC. The final statement noted that DAS Air should have had a clear understanding of the potential for the minerals to have been sourced from Eastern DRC. The NCP found that the airline undertook insufficient due diligence on the supply chain. The fact that the statement was issued in 2008 after the UN Framework introduced the human rights due diligence concept, but before it was introduced into the OECD Guidelines, has been found to indicate that the NCP explicitly considered the UN Framework a normative source. ${ }^{51}$ By reasoning that the airline, whose business is to provide transportation services, should have undertaken due diligence in regard to the supply chain for the products it was transporting for its customer, the statement provided an early elaboration of the substantive actions inherent in risk-based due diligence with regard to harmful human rights impacts and directly linked business relationships. In its recommendations the NCP noted that all UK businesses are expected by the government to follow international conventions and committed to sharing the statement with relevant trade organisations, ${ }^{52}$ thus expanding the audience of the statement to all UK-based companies in the sector.

In Global Witness vs. Afrimex, ${ }^{53}$ the minerals company Afrimex was alleged to have sourced minerals from mines using child labour and forced labour and to have subjected labourers to unacceptable health and safety conditions. Afrimex argued that it was removed from the mines in several steps. In its statement, issued two years before the 2011 revision of the Guidelines, the NCP referred to the UN Framework's concepts of due diligence and leverage. It concluded that Afrimex exercised insufficient supply chain due diligence and failed to take adequate steps to abolish child and forced labour or to take steps to influence working conditions in the mines. Hence, the statement contributed an elaboration of risk-based due diligence as well as of the corporate responsibility to exercise leverage.

\footnotetext{
${ }^{46}$ Guidelines, Procedural Guidance, Commentary 25.

${ }^{47}$ Lawyers for Palestinian Human Rights vs. G4S, UK NCP (27 November 2013).

${ }^{48}$ See discussion in Ceyhan (2017, n 8). 254.

${ }^{49}$ E.g., Backer (n 11); Ruggie and Nelson (n 11); Ceyhan (2017, n 8).

${ }^{50}$ RAID v Das Air, UK NCP, Final Statement, 1 July 2008.

${ }^{51}$ Ruggie \& Nelson (n 11).

${ }^{52}$ RAID vs. Das Air (n 50), paras. 51 and 56.

${ }^{53}$ Global Witness vs. Afrimex, UK NCP (28 August 2008).
} 
Survival International vs. Vedanta ${ }^{54}$ concerned allegations of inadequate stakeholder engagement by a mining company for a projected bauxite mine in India. The NCP final statement explained that Vedanta had failed to put in place an adequate and timely consultation mechanism to fully engage with an indigenous community thatwould be affected by the impact of its operations on the environment and health and safety. The company has also failed to use other mechanisms to assess the implications of its activities on the community, such as a human rights impact assessment. The statement contributed an elaboration of what is entailed in exercising meaningful stakeholder consultation as part of due diligence.

In NBIM/POSCO, involving the Norwegian Bank Investment Management (NBIM) and a Korea-based steel-producing company POSCO,${ }^{55}$ the complaint alleged that NBIM has failed to take appropriate steps to prevent or mitigate negative human rights and environmental impacts in connection with its investment in POSCO. The Norwegian NCP contributed to clarifying that minority investors are not relieved of the responsibility to exercise leverage as part of their due diligence in business relationships with which the company is directly linked through its investment. ${ }^{56}$ As many institutional investors are minority investors, the implications of this case are extensive. Spurred by confirmation from the Office of the UN's Office of the High Commissioner on Human Rights that institutional investors are indeed covered by the UNGP, the OECD launched a project to elaborate what risk-based due diligence entails for these economic actors. ${ }^{57}$

Of the above cases, all apart from the NBIM/POSCO were handled by the UK NCP. There is no reason to assume a priori that other NCPs do not also handle important cases, which can offer specific or general guidance for risk-based due diligence with regard to human rights. To test this, the following sections engage in an exemplary analysis of NCP statements on human rights due diligence. To qualify the analysis, it is preceded by an account of the steps taken for identifying and selecting the NCP statements. This demonstrates that the full potential of analysis of NCP cases as a method for extracting insights on due diligence currently encounters some complexities.

\section{Selecting NCP statements for analysis of due diligence guidance 4.1. Search options}

Three databases provide information on complaints handled by NCPs.${ }^{58}$ OECD's database is the official NCP database and comprises complaints since 2000. TUAC, a labour organisation with OECD standing, and OECD Watch, a civil society organisation, run databases of NCP cases as well. ${ }^{59}$ Those are organised around the focal area of the hosting organisation (for example, the TUAC base covers labourrelated cases). A detailed search can include all three databases. This is likely to grant several overlaps, but offers a broader range of search options. In addition, some NCPs offer listings of the complaints that they have handled.

The OECD database provides search options that can be combined, e.g. NCP country, theme (corresponding to the Guidelines' chapter headings), date, host country, source (who lodged the

\footnotetext{
${ }^{54}$ Survival International $v$ Vedanta Resources plc, UK NCP (25 September 2009).

${ }^{55}$ Complaint from Lok Shakti Abhiyan, Korean Transnational Corporations Watch, Fair Green and Global Alliance, and Forum for Environment and Development vs. POSCO/South Korea, ABP/APG (Netherlands) and NBIM (Norway), NCP of Norway (27 May 2013).

56 This was one of several complaints handled by different NCPs in regard to POSCO. As the complaints differed, NCP statements also relate to different issues (compare fn. 27).

${ }^{57} \mathrm{OECD}$, Responsible business conduct for institutional investors: Responsible business conduct for institutional investors: Key considerations for due diligence under the OECD Guidelines for Multinational Enterprises (2017 OECD)., supra note 19; Global Forum on Responsible Business Conduct, Scope and application of 'Business Relationships' in the financial sector under OECD's Guidelines for Multinational Enterprises (2015 OECD), available at https://mneguidelines.oecd.org/globalforumonresponsiblebusinessconduct/GFRBC-2014-financial-sector-document-2.pdf (accessed 10 October 2018).

${ }^{58}$ For details, see Ceyhan (this issue).

59 TUAC's database: http://www.tuacoecdmneguidelines.org/Cases.asp? organisationid=22752\&NCP=Y; OECD Watch database: https://www.oecdwatch.org/cases (both accessed 11 October 2018).
} 
complaint) and status of case (concluded or in progress), but displays precision weaknesses. Searches may generate hits for cases that were concluded as falling outside the scope of the Guidelines. 'Human rights' can be searched through the theme option (related to the Guidelines Chapter IV). 'Due diligence' is not a searchable theme in itself but can be searched under 'General Principles', the title of the Guidelines' Chapter II covering due diligence. As that chapter also covers other issues, a search on 'general principles' may result in hits that do not concern due diligence. Searches can be narrowed by the use of the advanced search option that allows for specific words, expressions, names etc, but may lead to imprecise results, e.g. in a search for 'human rights due diligence' if NCP statements may divide the words.

Identifying cases related to due diligence requires a content analysis of the information generated by a search, including the NCP statement. Das Air and Afrimex show that pre-2011 statements may address an issue substantively fitting the 'due diligence' term. Even since the 2011 revision NCPs may address due diligence without using that term, or address sub-concepts without using the Guidelines' exact terminology. For example, impact assessment is an integrated part of the risk-based due diligence process according to the UNGP. ${ }^{60}$ Yet, as seen below, some NCP statements refer to impact assessment without explicit reference to due diligence, and some final statements refer to engagement with affected stakeholders, which according to the UNGPs and OECD's Guidelines, also constitutes a significant element of risk-based due diligence. Moreover, some cases concerning 'due diligence' do not appear in the database under 'general principles', despite the concept being used in the complaint, agreement between the parties and/or NCP's final statement. This appears to be related to the keywords used by the NCP in reporting the case. A detailed identification of cases therefore cannot rely only on a search of the OECD database.

For this reason, a content analysis of the summary information and specific statement generated by a search on 'General Principles' was required to identify NCP statements concerning due diligence.

The OECD Watch database enables searches of specific terms, e.g. 'due diligence' ${ }^{61}$ It also offers an advanced search option, e.g. of company names, complainants, countries, chapters and paragraphs in the Guidelines, case status, keywords and sectors. Unlike the OECD database, these searches cannot currently be combined, thereby limiting the cross-searching capacity. TUAC's database allows one to search options based on three criteria: all cases, closed cases, and overdue cases. It does not enable a term search, but does offer a brief summary of the key issue in each case. ${ }^{62}$ Complementing a search of the OECD database by searches of the OECD Watch and TUAC databases increases the likelihood of relevant hits, but does not obviate the need for a content analysis to identify relevant cases.

\subsection{Steps taken to identify NCP statements concerning human rights due diligence for the current analysis}

For the sake of simplicity and due to space constraints, the following exemplary search for cases on human rights and due diligence is based only on the official source, the OECD database.

We adopted a combination of targeted searches and content analysis. First, a search with a combined application of the search criteria of 'general policies' (theme) and 'concluded cases' (status) generated a case body of $82 \mathrm{NCP}$ cases registered as 'specific instances'. ${ }^{63}$ A separate search for concluded cases on the theme of human rights generated 94 hits. ${ }^{64} \mathrm{~A}$ combined search on 'human rights', 'general

\footnotetext{
${ }^{60} \mathrm{GP} 19$.

${ }^{61}$ https://www.oecdwatch.org/search?portal_type=Case\&SearchableText=due+diligence (accessed 11 October 2018).

${ }^{62} \mathrm{http} / / /$ www.tuacoecdmneguidelines.org/Cases.asp (accessed 11 October 2018)

${ }^{63} \mathrm{http}: / /$ mneguidelines.oecd.org/database/searchresults/?hf $=10 \& \mathrm{~b}=0$ \& $\mathrm{r}=-\mathrm{f} \% 2 \mathrm{Fmne}$ mne theme\%2Fgeneral+policies $\& \mathrm{r}=-$ $\mathrm{f} \% 2$ Fmne currentstatus $\% 2$ Fconcluded $\& \mathrm{q}=! \mathrm{H}$ ! all \&s=desc(mne datereceived) (accessed 11 October 2018)

${ }^{64} \mathrm{http}: / /$ mneguidelines.oecd.org/database/searchresults $/ ? \mathrm{hf}=10 \& \mathrm{~b}=0 \& \mathrm{r}=-\mathrm{f} \% 2 \mathrm{Fmne}$ currentstatus $\% 2 \mathrm{Fconcluded} \& \mathrm{r}=-$ f\%2Fmne mne theme\%2Fhuman+rights\&q=!H!all\&s=desc(mne datereceived) (accessed 11 October 2018)
} 
principles' and 'concluded cases' generated 54 hits, ${ }^{65}$ but was found to include complaints that were rejected as falling outside the Guidelines. ${ }^{66}$ An advanced search of 'due diligence' as exact wording among concluded cases generated 19 hits. ${ }^{67}$ Narrowing that by adding 'human rights' as a theme generated 3 hits. ${ }^{68}$ This proved to deliver imprecise results, tested by examining whether concluded cases with a known human rights and due diligence focus were listed. Surprisingly, neither Das Air, Afrimex or Vedanta (discussed in the previous section) appeared. This may be because they preceded the 2011 revision of the Guidelines and therefore the introduction of 'due diligence' in the Guidelines' own language. The hit also excluded PWT Group,${ }^{69}$ despite the database summary including 'due diligence' and 'human rights', as well as NBIM/POSCO. This reinforced the merits of conducting a content analysis of the database summary and NCP statements.

The concluded cases on human rights and due diligence were subjected to a second content analysis, aiming to identify whether and how they addressed due diligence or sub-elements of the due diligence process in regard to corporate-related human rights harm. This generated a case body of $23 \mathrm{NCP}$ statements that explicitly refer to due diligence, and six that implicitly do so by reference to key subelements. Based on the UNGP and the Guidelines, the following issues were identified as key subelements: directly linked business relationships, leverage and use of influence; meaningful stakeholder consultation; impact assessment; and integrating and acting upon findings. Those 29 statements constituting the overall case body were subject to a further content analysis to identify what information they provided on due diligence or sub-issues. Thirteen were found to contribute substantive direction on due diligence or its sub-elements. The difference between the total case body and the number of statements offering specific guidance may be a result of divergent NCP practices in regard to use and specificity of final statements to express criticism and issue recommendations.

As seen in table 1 (below), the statements identified were issued by a relatively low number of NCPs. Section 5.6. reverts to the questions this raises in regard to how NCPs collectively fulfil their potential to offer guidance. The following exemplary analysis highlights guidance on human rights due diligence based on the body of thirteen cases, but due to space limitations excluding Raid/DAS Air, Afrimex and Vedanta as their main findings have been noted already. NBIM/POSCO is included as it informs other NBIM cases.

\section{Exemplary analysis of insights on due diligence from NCP statements}

No uniform pattern exists as to how NCP cases are referenced. The practice of using 'versus/vs.' between the names of the parties (e.g., RAID vs. Das Air) is common for UK NCP cases. As it emulates the style used for court cases, it may read as a conflict-type situation that differs from the conciliatory approach preferred by the Guidelines. In the subsequent analysis, cases are referenced in short form based on the company names.

Sections 5.1-5.5. analyse NCP statements organised according to main topics. Some overlaps are inevitable. 5.6. sums up insights in table 1 and reflects on the role and potential of NCPs in providing guidance.

\footnotetext{
${ }^{65} \mathrm{http}: / /$ mneguidelines.oecd.org/database/searchresults/?hf=10\&b=0\&r=-f\%2Fmne currentstatus $\% 2 \mathrm{Fconcluded} \& \mathrm{r}=-$ f\%2Fmne mne theme\%2Fhuman+rights\&r=-

f\%2Fmne_mne_theme\%2Fgeneral+policies\&q=!H!all\&s=desc(mne_datereceived) (accessed 11 October 2018).

${ }^{66}$ E.g., a case on patent violations in Denmark (http://mneguidelines.oecd.org/database/searchresults/?hf $=10 \& b=0 \& \mathrm{r}=-$

f\%2Fmne_mne_theme\%2Fgeneral+policies\&r=-f\%2Fmne_mne_theme\%2Fhuman+rights\&r=-

f\%2Fmne_currentstatus $\% 2 F$ concluded $\& q=! H !$ all $\& s=$ desc(mne_datereceived) and

http://mneguidelines.oecd.org/database/instances/dk0012.htm, accessed 11 October 2018).

${ }^{67} \mathrm{http}: / /$ mneguidelines.oecd.org/database/searchresults/?hf $=10 \& \mathrm{~b}=0 \& \mathrm{r}=-$

f\%2Fmne currentstatus $\% 2$ Fconcluded \&q=due+diligence (accessed 11 October 2018)

${ }^{68} \mathrm{http}: / /$ mneguidelines.oecd.org/database/searchresults/?hf $=10 \& \mathrm{~b}=0 \& \mathrm{r}=-\mathrm{f} \% 2 \mathrm{Fmne}$ currentstatus $\% 2 \mathrm{Fconcluded} \& \mathrm{r}=-$ f\%2Fmne mne theme\%2Fhuman+rights\&q=due+diligence (accessed 11 October 2018).

69 The hit also excluded PWT Group and the NGOs Clean Clothes Campaign Denmark and Active Consumers, NCP of Denmark (15 October 2016), despite the database summary including 'due diligence' and 'human rights'.
} 


\subsection{Due diligence in general, including state guidance under the state duty to protect}

Mylan concerned a pharmaceutical company manufacturing and selling a generic medicine that was deployed in the US for the execution of prisoners sentenced to death. The complaints alleged the company failed to observe the Guidelines' chapters on general principles and human rights in regard to sales in the US. ${ }^{70}$ The parties accepted the NCP's mediation offer, and after a meeting agreed to continue a constructive dialogue. In its final statement, the NCP took the opportunity to issue recommendations that encouraged pharmaceuticals in general to work with stakeholders such as distributors, human rights organisations and others to prevent medicines being misused for lethal purposes. It recommended that the company share the outcome of its own subsequent stakeholder engagement and its due diligence steps with other pharmaceuticals. The statement encouraged Dutch companies in general to incorporate the Guidelines into their policy and annual reports.

Sjøvik concerned allegations whereby, in catching fish and operating a fish processing plant in the territory of Western Sahara through its subsidiaries, the company failed to respect the right to selfdetermination of the Sahrawi people, thereby violating the Guidelines' human rights chapter. ${ }^{71}$ Western Sahara is claimed by Morocco, but recognised by the UN as a Non-Self-Governing Territory. Following mediation the parties reached an agreement. Since mediation led to a settlement, the NCP did not examine the case in detail. However, in its final statement it took the opportunity to underscore how companies operating in or from conflict areas are subject to heightened due diligence expectations, thereby elaborating the practical implications of the UNGPs for companies operating in conflict-affected areas. This is related to due diligence for companies as issues of context, ${ }^{72}$ and to the state duty to protect through making it clear that home states should provide guidance to companies operating in conflictaffected areas to help them avoid involvement in gross human rights abuses. ${ }^{73}$ This was based on the parties' agreement to request Norwegian authorities to provide unambiguous advice to businesses operating in conflict areas to allow them to handle political or other circumstances affecting decisions on, for example, rights to self-determination of certain groups. This statement provides insights for governments as well as other companies in highlighting the potential for home-state guidance, and to help other NCPs ask their governments to deliver such guidance.

The statement encouraged the company to involve human rights impact assessment expertise in the evaluation of its activities in Western Sahara. Relating to the UNGP's recommendation that business enterprises collaborate with experts for human rights policy development and impact assessment,${ }^{74}$ the statement may spur companies' appreciation of such expertise through a practice-related example illustrating some of the complexities involved in fully assessing human rights risks without expertise.

The original NBIM/POSCO complaint $^{75}$ concerning NBIM was followed by others with related allegations against NBIM. The NCP's statements in NBIM/Daewoo/POSCO and NBIM/Crown Investment $^{76}$ referred back to its statement in $P O S C O$, helping to clarify the attention to due diligence expected of a minority shareholder. The NCP observed an investor who is directly linked to the invested company through its relationship as a shareholder in the company should investigate whether allegations against that company are well-founded. Making detailed recommendations, the NCP listed actions for minority investors generally, such as identifying human rights risks in invested sectors or types of investments and develop a strategy to address these. The NCP commended the investor (NBIM) for its

\footnotetext{
70 Bart Stapert v Mylan, Netherlands NCP (11 April 2016).

${ }^{71}$ Norwegian Support Committee for Western Sahara $v$ Sjovik, NCP of Norway (5 May 2011).

${ }^{72}$ GP 23 with commentary.

${ }^{73}$ GP 7 with commentary.

${ }^{74}$ GPs 16 and 18.

${ }^{75}$ See fn. 55.

76 The Cotton Campaign, Anti-Slavery International and KTNC Watch concerning the Government Pension Fund Global's investments in the Korean companies Daewoo International and POSCO [NBIM/Daewoo/POSCO], NCP of Norway (2 July 2014); United Steel Workers and Birlesik Metal IS concerning the Government Pension Fund Global's investments in the US company Crown Holdings Inc [NBIM/Crown Investment], NCP of Norway (2 July 2014)..
} 
detailed strategy in regard to child labour but found that human rights due diligence must address the whole range of human rights that may be relevant to investments. Jointly the statements help investors and other financial institutions, as well as NCPs and other stakeholders, understand the extent of minority investors' responsibility to exercise human rights due diligence to identify and manage harm.

Rabobank also concerned institutional investors. The complaint alleged that Rabobank, a large financial institution, did not observe the Guidelines in Indonesia through its business relationship with a local agri-business group whose activities in Indonesian palm-oil were partially financed by Rabobank. ${ }^{77}$ The NCP noted that the Guidelines' reference to services (which leans on the language of the UNGPs) is applicable to any financial service, including lending. Also speaking directly to a larger audience in the sector it urged financial institutions to take part in due diligence initiatives, emphasising the value of a constructive 'multi-stakeholder dialogue.

\subsection{Directly linked business relationships}

In line with NBIM/POSCO, statements on later related cases, NBIM/Daewoo/POSCO and NBIM/Crown Investment treated the investor-investee relations as a directly linked business relationship in the sense of the UNGPs

In Mylan the NCP noted that 'business relationships' included distributors and purchasers of a product (in casu, drugs) distributed or purchased for purposes inconsistent with approved labelling and applicable medical standards.

PWT Group concerned allegations that a clothing company had failed to carry out due diligence in relation to a manufacturer located in the Rana Plaza building at the time of the building's collapse in 2013. ${ }^{78}$ In its final statement the NCP observed that because the manufacturer supplied to PWT group, the company was directly linked to the supplier.

\subsection{Leverage}

Following the reasoning that investor-investee relations are a directly linked business relationship, the statements concerning NBIM and POSCO, Daewoo and Crown Investment encouraged investors to collaborate with other investors to increase their leverage. The statements also recommended that investors use their leverage to encourage portfolio companies to put into place operational level grievance mechanisms and in general meet their own responsibilities to respect by being clear about the investors' expectations. This was highlighted for portfolio companies operating in sectors or regions in which the risks of human rights impacts are particularly high. Investors were encouraged to exercise shareholder voting rights and use dialogue to prompt the invested company to respect human rights. It was emphasised that all three core components of the responsibility to respect set out in the UNGPs are relevant for leverage: adopting a policy commitment to human rights, conducting human rights due diligence, and providing or cooperating in remediation. These recommendations give investors, investees, and other companies an opportunity to understand how they can focus their leverage, including how they can engage with remediation. Realising that operational-level grievance mechanisms can help prevent small issues from becoming significant sources of conflict, and invested companies in avoiding and mitigating human rights impacts, can reduce the negative human rights impacts to which investors might be linked through their business relationships. It can also help focus attention on the benefits of engaging actively with business relationships in order to support them, through technical or human rights knowledge, in addressing risks of adverse human rights impacts in their value chain. Using wording very similar to the text of the UNGPs and OECD's Guidelines, the NCP added more detail and operational guidance for (investor) companies to exercise leverage.

${ }^{77}$ Rabobank, Bumitama Agri Group (BGA) and the NGOs Friends of the Earth Europe and Friends of the Earth Netherlands/Milieudefensie, Netherlands NCP (15 January 2016).

78 (n 69). 
In Rabobank, the final statement acknowledged Rabobank's membership of the Roundtable for Responsible Palm Oil (RSPO), a multi-stakeholder initiative, but emphasised that financial institutions have a responsibility of their own to exercise individual leverage to seek to prevent or mitigate the impact of their business conduct and to increase their leverage if necessary with regard to their own clients.

$G 4 S$ also concerned due diligence in relation to business partners. ${ }^{79}$ The complaint concerned the operations of the security company G4S in Israel and the Palestinian Authority, alleging that the company's equipment, facilities, and operations were in breach of or associated with breaches of international human rights laws and principles. Among recommendations that add operational detail to the exercise of due diligence in conflict areas and which may also be of use to other companies, the final statement urged G4S to design and implement a contract approvals process across its operations, which would include assessment of human rights risks and application of mitigation steps. The statement offers guidance for companies delivering services or equipment that may be deployed to harm human rights. Guidance on contractual governance to constrain the actions of business relations can be of use to many types of companies. For example, in an incident involving a Danish pharmaceutical company that had been involved in allegations of selling a drug that was wrongly used to kill rather than to cure, the company developed a restricted distribution system to avoid the drug being used against the pharmaceutical's intentions. ${ }^{80}$ Quite similar to the Mylan case, that incident did not cause an NCP complaint, but the solution exemplifies how contracts can be deployed to direct the use of a product in the value chain. Knowledge ofpotential usage of contractual governance as a relevant modality for reducing human rights risks can become more widely spread if included in NCP recommendations.

\subsection{Meaningful stakeholder consultation and effective stakeholder engagement}

In Rabobank, the general recommendation that financial institutions take part in due diligence initiatives emphasised the value of a constructive multi-stakeholder process and the need to consider the views and concerns of affected stakeholders. This adds operational detail to meaningful stakeholder consultation in accordance with the UNGPs by reminding companies to include potential or actual victims, preferably in a direct conversation. In the palm-oil industry and other agri-business areas, small-scale farmers are often affected, but impact assessment processes tend to neglect steps needed to understand their views. ${ }^{81}$

Specific steps to be taken in stakeholder engagement to involve victims was also an issue in $G C M$ Resources. The complaint concerned displacement of local populations and environmental degradation resulting from a coalmine project in Bangladesh, ${ }^{82}$ and an alleged failure of the company to respect the rights of communities in that area. The final statement urged the company to identify appropriate ways to re-engage with affected communities, increase the information available to them, and take account of their views. Thus, the NCP underscored the need of effective stakeholder engagement to identify and understand the views and concerns of potential or actual victims, and offered guidance for use by other companies to re-establish soured relations with affected stakeholders with a view to enabling meaningful stakeholder engagement looking ahead.

The Statkraft ${ }^{83}$ case concerned whether the energy company Statkraft had taken account of the interests of a Saami village and respected the human rights of the villagers, including in regard to consultation. The reindeer herding collective lodging the complaint acknowledged that Statkraft had consulted with the community during the planning stages of the wind power plant, but contended that 'meaningful engagement' had not taken place. They alleged non-observance of the right of indigenous

\footnotetext{
79 (fn. 47).

${ }^{80}$ Karin Buhmann and Line Pedini Rasmussen, Lundbeck's Pentobarbital Human-Rights Dilemma, or When Good Intentions Turn Lethal: Issue management in a CSR context. Teaching case. (2015 The Case Centre and Copenhagen Business School).

${ }^{81}$ E.A. Zoomers and K. Otsuki, 'Addressing the impacts of large-scale land investments: Re-engaging with livelihood research', 83 Geoforum, 164-171.

82 IAC \& WDM v GCM Resources plc, UK NCP (20 November 2014).

83 Jijnjevaerie Saami village and Statkraft, NCP of Sweden and Norway (2 August 2016)
} 
peoples to free, prior and informed consent (FPIC) under ILO's convention 169, a convention that relates to human rights but does not form part of the International Bill of Rights or the ILO fundamental conventions considered as the minimum base-line for the corporate responsibility to respect human rights, according to the UNGP. The two collaborating NCPs (Norway and Sweden) did not find that Statkraft had failed to comply with the OECD Guidelines, but issued recommendations for actions the company might consider. This included clearly to promote indigenous people's rights, thereby complementing the normative baseline of the UNGP and OECD's Guidelines by clarifying that companies are not limited to observing the International Bill of Rights and ILO's fundamental conventions. A company can go beyond that baseline and include additional human rights instruments in its due diligence process; highlighting the particular relevance of ILO convention 169 in indigenous or tribal areas.

\subsection{Assessing impacts; integrating and acting upon findings}

In NBIM/POSCO, NBIM/DAEWOO/POSCO and NBIM/Crown Investment, the NCP recommended that investors establish and integrate a system to identify the heightened risk of potential human rights violations into their general screening of companies for potential investment. In line with the UNGPs' general recommendations the NCP recognised that the system may need to prioritise, based on the risk of human rights impacts, and that the priorities could be identified through factors such as sector, country of operations, or other variables. Explaining this in the statement helps unpack the UNGPs for institutional investors by applying the UNGP's wording in the context of the OECD Guidelines. The statement also explained that when serious or systematic human rights violations are identified prior to investment, the investor should put a procedure in place to consider non-investment, thereby weighing the gravity of the abuses, as well as the potential for the investor to engage with the company and bring about change. This echoes the language of GP 19 and its commentary, but whereas the UNGPs most obviously address conventional supply-chains, the NCP explains the situation in a manner that addresses institutional investors.

The PWT Group statement found that the company failed to take appropriate measures to identify, prevent or remedy adverse impacts linked to the supplier's operations in regard to employees' human and labour rights, including occupational health and safety. The statement noted that replicating what other companies in a sector do does not relieve a company of individual responsibility to assess impacts and integrate and act on findings.

\subsection{Summary and reflections}

Table 1 sums up the insights on due diligence provided by NCPs in their final statements analysed above.

\section{[insert Table 1 around here]}

The analysis confirms the assumption that NCP statements can provide important guidance on due diligence and its various sub-elements. It confirms that in dealing with company conduct in specific sectors and contexts, NCP statements are important sources of normative guidance that help define the details of due diligence. The contextual aspect and recommendations developed with the knowledge of specific company operations that gave rise to complaints are important complements to the general guidance texts issued by the OHCHR and the OECD. It is not unrealistic to imagine that detailed statements and recommendations can help shape a coherent NCP jurisprudence, in turn contributing to functional equivalence of NCPs and legal certainty for victims, companies, and other stakeholders, such as business relationships. Studying NCPs' statements can be therefore also be relevant sources of norms for businesses as well as for scholars or organisations interested in responsible business conduct.

The table shows that the ten complaints leading to substantive statements on due diligence were handled by a total of four NCPs: six by Norway (including the three NBIM cases, and one with Sweden's NCP); 
two by the Netherlands, two by the UK, and one by Denmark's NCP. In addition, Das Air, Afrimex and Vedanta were also handled by the UK NCP. These NCPs are all among those that enjoy the highest degree of independence according to the OEDC. ${ }^{84}$ Whether this plays a role in the NCPs' use of specific statements to develop detailed guidance on due diligence exceeds the bounds of the current analysis. However, the limited number of NCPs actively making recommendations to clarify human rights due diligence does indicate a considerable potential for other NCPs to also contribute to providing guidance through their final statements.

The analysis also shows that NCPs do not apply uniform language or terminology in their findings and recommendations, and indeed often appear to prioritise language that is easy to understand for managers, rather than deploying a wording that exactly reflects the Guidelines or UNGPs' language. In this, NCPs appear to take the pragmatic approach of contributing to operationalisation. Unlike courts they do not limit themselves to a strict assessment of whether a standard of conduct has been respected. Rather, they interpret the standards as aspirations in context, and explain why certain actions were not in accordance with those aspirations, and how the aspirations may be better met in future actions. This may also be due to the composition of NCPs, which are often made up of a diverse range of actors with various backgrounds as academics and practitioners. ${ }^{85}$ While this sets NCP statements apart from court judgements, it does not decrease their relevance as forward-looking sources of guidance for companies or for other NCPs in their role to promote what due diligence and its sub-elements entail. In fact, communicating in a manner that speaks to the logic of managers is in accordance with the UNGPs and certain other public guidance instruments for responsible business conduct. ${ }^{86}$ On the other hand, the lack of a uniform language may make it more complicated for victims or other stakeholders to hold companies to account. This also includes NCPs acting in their remedial role.

\section{Conclusion}

As in case law, NCP statements can offer insights into the general normative expectations or requirements of conduct with regard to a substantive issue or in a context. The findings in this article demonstrate that NCP statements can be valuable sources of detailed guidance, e.g. on what risk-based due diligence entails. This confirms that studying NCP statements offers a method for identifying details on norms of conduct for businesses to act in accordance with the UNGP. Similar to judicial case law, insights from such cases can be applied pro-actively by other companies to avoid causing abuse. As the Guidelines require due diligence of firms across most of the Guidelines' issue areas - disclosure, human rights, labour (employment/industrial issues), environment, consumer interests and anti-corruption there is considerable potential for learning across sectors and NCPs.

A detailed study of NCP statements to extract guidance on due diligence can complement existing literature and guidance texts from OHCHR and OECD for companies and other stakeholders to understand what risk-based due diligence entails. As one NCP statement can also be a source for other NCPs, enhanced systematic study of how individual NCP statements clarify and construct specific standards of conduct set out by the Guidelines can help NCPs develop a coherent body of jurisprudence. This may go beyond the resources of individual NCPs but could be systematically performed by the OECD.

Explaining how an analysis of NCP statements may be conducted, the article introduces the OECD, TUAC and OECD Watch databases, designs an exemplary search, and proceeds to analyse the identified NCP statement to draw out insights on due diligence and its sub-elements, in particular general guidance on due diligence, directly linked business relationships, leverage and use of influence, meaningful stakeholder consultation, assessment of impacts and integrating and acting upon findings.

\footnotetext{
84 OECD (n 13).

85 OECD, n. 13.

${ }^{86}$ Karin Buhmann, Changing sustainability norms through communicative processes: the emergence of the Business \&

Human Rights regime as transnational law (2017 Edward Elgar).
} 
The process of identifying cases for analysis can be assisted by the online databases and search terms. The opportunities offered by online search options are not currently adequate to fully identify relevant complaints and NCP statements. This must be complemented by a content analysis designed to identify whether the substantive aspects of specific concepts are addressed in a statement.

The analysis shows considerable variety in the degree of specificity offered by NCP statements. Some are quite detailed in terms of criticism and recommendations, others much less so. Some lend themselves easily to extracting guidance for companies to understand what is expected of their due diligence practices and for stakeholders to hold companies to account for such practices. Other statements are much less specific and provide much less future-oriented guidance. While the diversity among NCP statements or in the practices of various NCPs in regard to issuing recommendations does not reduce value of NCP statements as sources of normative guidance, it does suggest there may be an unfulfilled potential for many of the currently 48 NCPs to provide more detailed guidance.

Whether such variety can be attributed to patterns such as NCP organisation and structure may be determined by future analysis. Moreover, further research may consider whether insights relevant to human rights due diligence can be extracted from NCP statements on other issues to which the OECD Guidelines also prescribe the exercise of risk-based due diligence (e.g., environmental impact).

Karin Buhmann, Professor of Business \& Human Rights, Department of Management, Society and Communication (MSC), Copenhagen Business School (CBS), Denmark 
Table 1: Summary of due diligence guidance from NCP cases analysed, organized according to NCP

\begin{tabular}{|c|c|c|c|c|c|c|c|}
\hline & NCP & $\begin{array}{l}\text { Due diligence in } \\
\text { general: } \\
\text { State's Duty to } \\
\text { Protect by } \\
\text { providing due } \\
\text { diligence } \\
\text { guidance for } \\
\text { companies }\end{array}$ & $\begin{array}{l}\text { Stakeholder } \\
\text { engagement }\end{array}$ & $\begin{array}{l}\text { Human rights } \\
\text { impact } \\
\text { assessment }\end{array}$ & $\begin{array}{l}\text { Directly } \\
\text { linked } \\
\text { business } \\
\text { relationships }\end{array}$ & Leverage & $\begin{array}{l}\text { Integrating } \\
\text { and acting } \\
\text { upon } \\
\text { findings }\end{array}$ \\
\hline PWT Group & Denmark & & & & $\begin{array}{l}\text { Includes } \\
\text { relationships to } \\
\text { suppliers }\end{array}$ & & $\begin{array}{l}\text { Individual } \\
\text { responsibility } \\
\text { to assess } \\
\text { mpacts and } \\
\text { act on } \\
\text { findings, } \\
\text { regardless of } \\
\text { practices in } \\
\text { sector }\end{array}$ \\
\hline Mylan & Netherlands & & $\begin{array}{l}\text { To avoid product } \\
\text { misuse } \\
\text { Companies to } \\
\text { integrate } \\
\text { Guidelines into } \\
\text { policies and } \\
\text { annual reporting }\end{array}$ & $\begin{array}{l}\text { Companies to } \\
\text { integrate } \\
\text { Guidelines into } \\
\text { policies and } \\
\text { annual reporting }\end{array}$ & $\begin{array}{l}\text { Includes } \\
\text { distributor and } \\
\text { purchasers }\end{array}$ & & \\
\hline Rabobank & Netherlands & &  & & $\begin{array}{l}\text { Guidelines } \\
\text { apply to } \\
\text { institutional } \\
\text { investors, } \\
\text { including } \\
\text { lenders } \\
\text { Membership of } \\
\text { stakeholder } \\
\text { initiatives does } \\
\text { not relieve a } \\
\text { company from } \\
\text { exercising } \\
\text { leverage on its } \\
\text { own } \\
\end{array}$ & & \\
\hline Sjøvik & Norway & $\begin{array}{l}\text { Connecting to } \\
\text { UNGP } 7\end{array}$ & & Use of expertise & & & \\
\hline
\end{tabular}




\begin{tabular}{|c|c|c|c|c|c|c|}
\hline & & $\begin{array}{l}\text { Explicating } \\
\text { connection } \\
\text { between Pillar } \\
\text { One and Pillar } \\
\text { Two }\end{array}$ & & & & \\
\hline $\begin{array}{l}\text { NBIM } \\
\text { (NBIM/POSC } \\
\text { O; } \\
\text { NBIM/Daewoo } \\
\text { /POSCO, } \\
\text { NBIM/Crown } \\
\text { Investment) }\end{array}$ & Norway & & $\begin{array}{l}\text { Use influence to } \\
\text { persuade directly } \\
\text { related business } \\
\text { relationships } \\
\text { (specifically: } \\
\text { investees) to } \\
\text { increase } \\
\text { stakeholder } \\
\text { engagement }\end{array}$ & $\begin{array}{l}\text { Guidelines } \\
\text { apply to } \\
\text { include } \\
\text { minority } \\
\text { investors => } \\
\text { Investors to } \\
\text { investigate } \\
\text { whether } \\
\text { allegations } \\
\text { against } \\
\text { invested } \\
\text { company are } \\
\text { true. }\end{array}$ & $\begin{array}{l}\text { Minority } \\
\text { investors to } \\
\text { collaborate } \\
\text { with other } \\
\text { investor to } \\
\text { increase } \\
\text { leverage } \\
\text { Make } \\
\text { expectations } \\
\text { of invested } \\
\text { companies } \\
\text { clear, at } \\
\text { executive } \\
\text { level } \\
\text { Use options } \\
\text { for } \\
\text { shareholder } \\
\text { voting and } \\
\text { dialogue } \\
\text { Leverage to } \\
\text { be part of } \\
\text { human rights } \\
\text { policy, due } \\
\text { diligence, } \\
\text { and } \\
\text { remediation } \\
\text { Use } \\
\text { influence } \\
\text { with } \\
\text { portfolio } \\
\text { companies, } \\
\text { esp. in risk- } \\
\text { areas, to } \\
\text { institute } \\
\text { operational- }\end{array}$ & $\begin{array}{l}\text { Establish } \\
\text { systems to } \\
\text { identify } \\
\text { heightened } \\
\text { risk } \\
\text { Prioritize } \\
\text { based on } \\
\text { risks and } \\
\text { severity } \\
\text { identified } \\
\text { through } \\
\text { specific } \\
\text { variables } \\
\text { Risk } \\
\text { mitigation, } \\
\text { suspension } \\
\text { or disengage }\end{array}$ \\
\hline
\end{tabular}




\begin{tabular}{|c|c|c|c|}
\hline & & & $\begin{array}{l}\text { level } \\
\text { grievance } \\
\text { mechanism } \\
\text { (remediation) }\end{array}$ \\
\hline Statkraft & $\begin{array}{l}\text { Norway } \\
\text { /Sweden }\end{array}$ & $\begin{array}{l}\text { Promote } \\
\text { indigenous } \\
\text { peoples rights, } \\
\text { e.g. FPIC/ILO } \\
\text { C169 } \\
\text { Go beyond the } \\
\text { minimum baseline } \\
\text { of the IBHR and } \\
\text { core labour rights }\end{array}$ & \\
\hline G4S & UK & & $\begin{array}{l}\text { Contracts } \\
\text { approval } \\
\text { process }\end{array}$ \\
\hline $\begin{array}{l}\text { GCM } \\
\text { Resources }\end{array}$ & UK & $\begin{array}{l}\text { Steps to identify } \\
\text { victims' views }\end{array}$ & \\
\hline
\end{tabular}

